\title{
Significance of relative coronary flow reserve in patient with microvascular dysfunction to differentiate significant coronary artery stenosis
}

Milorad Tesić1,2, Ana Djordjević-Dikići, ${ }^{1,2}$, Dimitra Kalimanovska Oštrić ${ }^{1,2}$, Nikola Bošković ${ }^{2}$, Goran Stanković1,2, Branko Beleslin ${ }^{1,2}$

${ }^{1}$ Clinic of Cardiology, Clinical Center of Serbia, Belgrade, Serbia, ${ }^{2}$ Faculty of Medicine, University of Belgrade, Belgrade, Serbia

Abstract

Introduction: Coronary flow reserve (CFR) is defined as a ratio of hyperemic-to-basal coronary flow velocity and it can be measured by a variety of methods. Transthoracic Doppler echocardiography (TTE) CFR became useful method to assess functional significance of coronary artery stenosis in both left anterior descending (LAD) and posterior descending coronary artery (PD). CFR is combined measure of the capacity of epicardial coronary artery and microcirculation to achieve maximal blood flow in response to hyperemic stimulation. Thus in patients with already impaired microcirculation and accordingly CFR, differentiation from presence of significant coronary stenosis is difficult without known coronary angiography.

Case report: We present a case of patient with hypertrophic cardiomyopathy and diabetes, where relative CFR as the ratio of the CFRs of two coronary arteries helped us in decision making to do coronarography because of atypical chest pain and fatigue.

Conclusion: In patients with known microvascular dysfunction and already impaired CFR, relative CFR might be helpful to differentiate presence of significant epicardial stenosis. Future studies are needed to obtain appropriate clinical implications of relative CFR in everyday practice.

Key Words coronary flow reserve; relative coronary flow reserve; microcirculation; hypertrophic cardiomyopathy

\section{Introduction}

oronary flow reserve (CFR) is defined as a ratio of hyperemic-to-basal coronary flow velocity and can be measured by a variety of methods including Doppler flow wire, positron emission tomography, cardiac magnetic resonance, transesophageal and transthoracic Doppler echocardiography (TTE). In recent years, TTE-CFR became useful method to assess functional significance of coronary artery stenosis in both left anterior descending (LAD) and posterior descending coronary artery (PD).

CFR is combined measure of the capacity of epicardial coronary artery and microcirculation to achieve maximal blood flow in response to hyperemic stimulation $^{1}$. Thus in patients with already impaired microcirculation and accordingly CFR, differentiation from presence of significant coronary stenosis is difficult without known coronary angiography. To overcome this limitation of the test, CFR might be done in another artery, since if there is no coronary artery stenosis CFR in both vessels should be similar, so the relative CFR as a ratio of these CFR values should be $\approx 1$.

We present a patient with asymmetric $\mathrm{HCM}$ and with diabetes where relative CFR helped us in decision making to do coronarography due to atypical chest pain and fatigue.

\section{Case report}

We present the 52 years old female patient who presented in our hospital with shortness of breath and fatigue during ordinary activity, without typical chest pain. She had known, diagnosed 20 years ago, history of HCM. Also patient had diabetes mellitus type II (on oral therapy last 10 years), hypertension and hyperlipoproteinemia. Family history for sudden death and coronary artery disease was negative.

Electrocardiogram reveled sinus rhythm, frequency of 56 beats per minute with negative T wave in D1, aVL, V3-V6 leads and ST elevation of $1 \mathrm{~mm}$ in D3 lead.

Physical finding was within normal limits, except the mild systolic (1/6) murmur at the apex.

TTE showed normal left ventricular end-diastolic dimension $(5.4 \mathrm{~cm})$ and end-systolic dimension $(3.2 \mathrm{~cm})$ with preserved ejection fraction of $70 \%$, without wall motion abnormalities. There were hypertrophic all apical segments of left ventricle, with maximal thickness of $1.6 \mathrm{~cm}$ of distal part of the septum. There was not either presence of left ventricular outflow tact obstruction or 


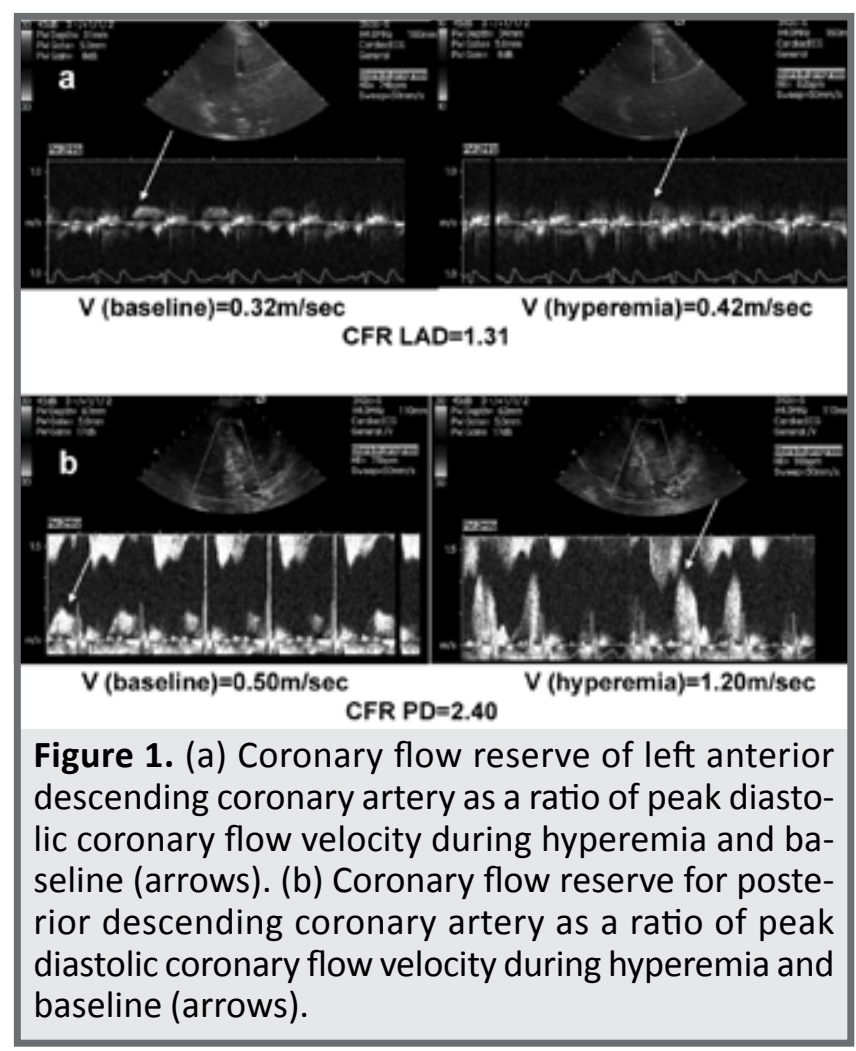

presence of systolic anterior motion of anterior mitral leaflet. All other echocardiographic parameters were within normal limits.

After TTE, in order to assess functional status of the coronary arteries and microcirculation we did CFR. Peak diastolic coronary flow velocity was measured in basal conditions and during maximal hyperemia, which was induced with adenosine $(0.14 \mathrm{mg} / \mathrm{kg} / \mathrm{min}$ intravenously, during 2 minutes). In basal conditions peak coronary flow velocity of LAD was $0.32 \mathrm{~m} / \mathrm{sec}$ and during hyperemia, peak coronary flow velocity was $0.42 \mathrm{~m} / \mathrm{sec}$, resulting in much decreased CFR LAD - 1.31 (Figure 1a). Since the CFR LAD result was very low, we did CFR for PD artery, where peak diastolic coronary flow velocity was $0.50 \mathrm{~m} / \mathrm{sec}$ in basal conditions and during hyperemia diastolic coronary flow velocity rose up to $1.20 \mathrm{~m} / \mathrm{sec}$ (Figure $1 \mathrm{~b}$ ). CFR PD was preserved- 2.4 and relative CFR (CFR LAD/CFR PD) was 0.54. Since there was such a difference in CFRs we decided to do coronary angiography. It revealed presence of significant ostial-LAD (70-80\%) (Figure $2 \mathrm{a}$ ) and mid-LAD (70-90\%) stenosis (Figure $2 \mathrm{~b}$ ), while the circumflex and right coronary arteries (Figure 2c) were without significant stenosis. Patient was referred to the cardiac surgery for bypass graft.

\section{Discussion}

It is know that even as a "stand alone" technique TTE-CFR $<2$ has good sensitivity $89-92 \%$ and specificity $75-93 \%$ to predict significant LAD and PD coronary artery stenosis ( $>70 \%$ diameter stenosis) ${ }^{2-4}$. CFR-TTE together with 2-dimensional echocardiography provide better sensitivity up to $93 \%$ and still good specificity $80.6 \%$ for detection of diseased LAD 5 . Also favorably results were recently published, showing that CFR-TTE is
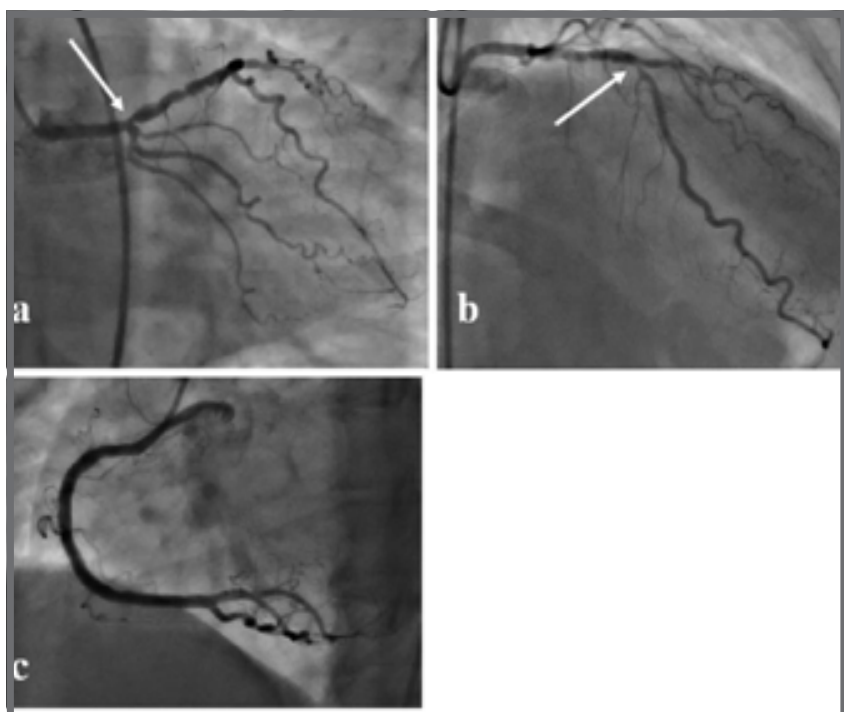

Figure 2. (a) Significant ostial lesion of left anterior descending coronary artery (arrow). (b) Significant lesion in medial segment of left anterior descending coronary artery (arrow). (c) Right coronary artery.

a helpful noninvasive tool in the decision making whether to proceed $\mathrm{PCl}$ or to continue treatment with medical therapy in patients with intermediate coronary artery stenosis ${ }^{1,6,7}$. On the other hand, in many clinical conditions such as hypertrophic cardiomyopathy (HCM), aortic stenosis, dilatative cardiomyopathy, diabetes, syndrome $X$ and presence of myocardial scar, there is impairment of microcirculation which is reflected with decreased CFR even though coronary arteries are without stenosis ${ }^{1,6-9}$. Thus in these patients prediction of significant stenosis is more difficult and there are more often false positive CFR tests. To overcome this limitation of the test, CFR might be done in another artery to examine if it has impaired CFR due to microvascular dysfunction. The ratio between CFR LAD and CFR PD, known as relative CFR, should be $\approx 1$ if there is no epicardial stenosis ${ }^{8}$. If the relative CFR is $\approx 1$ and stress echocardiographic test is negative, we might exclude presence of severe coronary artery stenosis.

In our recent paper we found that in patients with asymmetric HCM, CFR for both LAD and PD is significantly lower compared to the control group ${ }^{8}$. Also, we found that in HCM patients without left ventricular outflow tract obstruction there is no significant difference between CFR LAD and CFR PD $(2.22 \pm 0.55$ vs. $2.27 \pm 0.50$, respectively, $p=n s$ ) and that relative CFR was $0.98 \pm 0.14^{8}$. So we believe that relative CFR can help us to differentiate presence of significant coronary artery stenosis in these patients with already impaired CFR due to microvascular dysfunction like in presented case report. Also quantification of the regional flow might be additive information to the stress echocardiography, because marked and segmental hypertrophy lowers the sensitivity to detect wall motion abnormalities during stress echocardiography. 


\section{Conclusion}

CFR-TTE can provide useful quantative information concerning the functional status of coronary arteries. In patients with known microvascular dysfunction and already impaired CFR, relative CFR might be helpful to differentiate presence of significant epicardial stenosis. Future studies are needed to obtain appropriate clinical implication of relative CFR in everyday practice to predict presence of significant stenosis in patients with impaired microcirculation.

\section{References}

1. Tesic M, Stankovic G. Invasive and non-invasive evaluation of intermediate coronary stenosis. Cardiology International 2010;11:97-98.

2. Matsumura $\mathrm{Y}, \mathrm{Hozumi} \mathrm{T}$, Watanabe $\mathrm{H}$, et al. Cut-off value of coronary flow velocity reserve by transthoracic Doppler echocardiography for diagnosis of significant left anterior descending artery stenosis in patients with coronary risk factors. Am J Cardiol 2003;92:1389-93.

3. Hozumi T, Yoshida K, Akasaka T, et al. Noninvasive assessment of coronary flow velocity and coronary flow velocity reserve in the left anterior descending coronary artery by Doppler echocardiography: comparison with invasive technique. J Am Coll Cardiol 1998;32:1251-9.

4. Takeuchi M, Ogawa K, Wake R, et al. Measurement of coronary flow velocity reserve in the posterior descending coronary artery by contrast-enhanced transthoracic Doppler echocardiography. J Am Soc Echocardiogr 2004;17:21-7.

5. Rigo F, Richieri M, Pasanisi E, et al. Usefulness of coronary flow reserve over regional wall motion when added to dual-imaging dipyridamole echocardiography. Am J Cardiol 2003;91:269-73.

6. Meimoun P, Benali T, Elmkies F, et al. Prognostic value of transthoracic coronary flow reserve in medically treated patients with proximal left anterior descending artery stenosis of intermediate severity. Eur J Echocardiogr 2009;10:127-32.

7. Rigo F, Sicari R, Gherardi S, Djordjevic-Dikic A, Cortigiani L, Picano E. Prognostic value of coronary flow reserve in medically treated patients with left anterior descending coronary disease with stenosis $51 \%$ to $75 \%$ in diameter. Am J Cardiol 2007; 100: 1527-31.

8. Tesic M, Djordjevic-Dikic A, Beleslin B, et al. Regional difference of microcirculation in patients with asymmetric hypertrophic cardiomyopathy: transthoracic Doppler coronary flow velocity reserve analysis. J Am Soc Echocardiogr 2013;26:775-82.

9. Tesic M, Seferovic J, Trifunovic D, et al. N-terminal pro-brain natriuretic peptide is related with coronary flow velocity reserve and diastolic dysfunction in patients with asymmetric hypertrophic cardiomyopat

\section{Sažetak}

\section{Značaj relativne koronarne reserve protoka kod pacijenata sa mikrovaskulrnom disfunkcijom u proceni značajne koronarne stenoze}

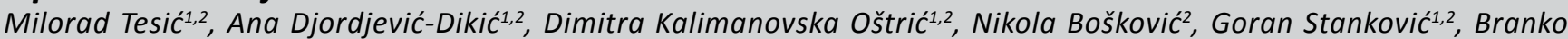
Beleslin ${ }^{1,2}$

${ }^{1}$ Klinika za kardiologiju, Klinički centar Srbije, ${ }^{2}$ Medicinski fakultet, Univerzitet u Beogradu

Uvod: Koronarna rezerva protoka (CFR) se definiše kao odnos maksimalne brzine protoka tokom hiperemije i u bazalnim uslovima koji može biti izmeren različitim metodama. Vrednost CFR-a kvantifikovana transtoraksnom Doppler ehokardiografijom postala je korisna metoda u proceni funkcionalne značajnosti stenoza prednje descedentne (LAD) kao i zadnje descedentne (PD) koronarne arterije. CFR je kombinovana mera kapaciteta epikardijalne koronarne arterije i mikrocirkulacije da bi se postigao maksimalni protok krvi u odgovoru na hiperemijsku stimulaciju. Zbog toga kod pacijenata sa već oštećenom mikrocirkulacijom i prema tome sniženom vrednosću CFR-a, diferenciranje prisustva značajne koronarne stenoze je teško bez poznate koronarne angiografije.

Prikaz slučaja: Predstavljamo slučaj pacijenta sa hipertrofičnom kardiomiopatijom i dijabetesom, gde je relativni CFR kao odnos CFR-ova dve koronarne arterije pomogao u donošenju odluka za koronarografiju zbog atipičnih bolova u grudima i zamora.

Zaključak: Kod pacijenata sa poznatom mikrovaskularnom disfunkcijom i već sniženim CFR-om, relativni CFR može biti od pomoći da se diferencira prisustvo značajne epikardijalne koronarne stenoze. Dodatne studije su potrebne kako bi se dobile odgovarajuće kliničke implikacije relativnog CFR-a u svakodnevnoj praksi.

Ključne reči: koronarna rezerva protoka, relativna koronarna rezerva protoka, mikrocirkulacija, hipertrofična kardiomiopatija. 